\title{
Bed Bunk Accommodation; Convergence of Online Promotion Media with Balinese Traditional Houses in Canggu Village, Bali
}

\author{
Ni Putu Suda Nurjani ${ }^{1}$, Syamsul Alam Paturusi ${ }^{2}$, Ngakan Ketut Acwin Dwijendra ${ }^{3}$ I Dewa Gede \\ Agung Diasana Putra ${ }^{4}$ \\ ${ }^{1}$ Student of Doctoral Program Engineering Science Udayana University \\ suda.nurjani@gmail.com ${ }^{1}$ \\ ${ }^{2}$ Lecture of Doctoral Program Engineering Science Udayana University \\ syamsul@unud.ac.id ${ }^{2}$ \\ ${ }^{3}$ Lecture of Doctoral Program Engineering Science Udayana University \\ acwin@unud.ac.id ${ }^{3}$ \\ ${ }^{4}$ Lecture of Doctoral Program Engineering Science Udayana University \\ diasanaputra@unud.ac.id ${ }^{4}$
}

\begin{abstract}
Bali is one of the most popular tourism destinations in the world with various forms of accommodation. Start from five star hotels until small lodgings built in each community residential unit. The strong custom and restrictions on tall buildings in Bali, making people look for various new alternatives to develop accommodation. The existence of local regulations that require the use of traditional Balinese ornamentation, requires accommodation owners to find adaptive accommodation development methods. However, with the development of the digital industry 4.0 specifically in contact with online advertising, there are no official rules in Bali that regulate it. This condition makes the demand for cheap accommodation in Bali seem unlimited. The promotion system no longer requires government legality. This phenomenon makes accommodations in remote places even can be accessed easily by all people in the world. The community then competes with each other to build cheap accommodations in their traditional homes. The government also cannot touch the spatial development caused by online media demand, due to the absence of regulations that limit it. This research tries to identify the bed bunk phenomenon that is built and operationalized through online promotion media, and has no legality. Data collection was carried out by direct observation of the object of study in Canggu village, district of North Kuta, Badung Regency, Bali Province. The findings of this study indicate that, bed bunk was born in Bali due to the high demand for backpacker tourists which is sufficient with wifi, table and bed facilities. The high cost of land in Bali encourages local people to build accommodations in their residential units. The maximum utilization of the interior (construction of 6-8 beds in one room) is the most preferred choice. This condition is due to vertical building restrictions that cannot exceed $15 \mathrm{~m}$ and economic factors (get maximum income on narrow land). This finding is expected to be used as an evaluation material for spatial improvement in Bali which has an impact on congestion throughout the tourist area due to uncontrolled accommodation development.
\end{abstract}

Keyword: Bed Bunk Accommodation, Convergence, Online Media

\section{INTRODUCTION}

$\mathrm{T}$ HE development of human civilization demands many changes in various fields. One of the most significant fields affecting human life today is change in the fields of communication and technology. In the past, communicating with distant relations was very calculated. Communication tools such as letters, telegrams until pagers and landlines appear, reflecting a change in human communication technology. Until the present mobile phones whose use is unlimited, not limited to communication, but can drive business and various fields of life. All of these communication tools are very dependent on the existence of the internet. Internet needs are increasing when shops begin to use the internet to start an online business. The seller starts interacting with customers through online media known as online shops. People in various parts of the world can exchange merchandise in various variants, in a short time for a low cost. How was the newspaper was very important to the community, and finally experienced a very significant 
change. The availability of online news on the internet, makes it easy for people to get various types of information very easily, without subscribing per month, people can access information wherever and whenever. According to Gerald A. Militer quoted by Onong Uchjana Effendy explained that:

"In the main, communication has its central interest in those behavioral situations in which sources transfer a message to a receiver with conscious intent to affect the latte's behavior".

Basically, communication contains an understanding of situations and behaviors as central interests, where a person as a resource conveys an impression to someone or a number of recipients who consciously aim to obtain behavioral characteristics (Effendy, 2002: 49)

Current media intersections not only affect conventional trading activities, but also affect spatial development. Promotion of tourist accommodation through online media, has increasingly accelerated the spread of tourists to various regions in Bali, to remote areas that do not yet have a good physical transportation network. This intersection from conventional media to digital media is called "convergence". One well-known convergence theory is the "Symbolic Convergence Theory". This theory was pioneered by Ernest Bormann (1989), this theory explains the process of exchanging messages that give rise to group awareness that results in the presence of meaning, motives, and also shared equality. Group awareness that is built up in a group can develop a kind of meaning, motive for acting for the people in the group. Symbolic convergence theory is a unique theory because it tries to put forward the importance of narrative or narrative factors in communication. That what is often discussed and considered important in a group context will ultimately reproduce the symbolic meaning and ultimately will determine the meaning or reality of a person. Symbolic convergence theory is a theory in the sociocultural tradition that examines language, fantasy, and fact symbols in the communication process. So that it is expected to be able to explain the shared meaning that appears in communication relations on webportal.

Traditional Balinese houses in general have many meanings. Not only does it function as a shelter from heat and rain, but many ritual meanings are contained within the building unit. In harmony with Max Weber's research that uses the "Verstehen" approach (understanding) of the meaning contained in social reality or behind human actions carried out by tracing values, beliefs, goals, and attitudes that guide human behavior and actions. The influence of the social structure of the family as residents of a traditional dwelling is assessed based on Verstehen's theory. Changes in trust make people form a new space that has spiritual value. The same is true for changes in the family economy. Motivation to obtain economic improvement, makes people add new functions in their homes. The addition of this commercial function opens opportunities for interaction between people outside the family. In some cases, the presence of this stranger influences the life of the original family. However, on the other hand, traditional life and family life can continue normally. The presence of internet media as one of the communication tools is increasingly encouraging the development of accommodation built in residential units. The community is now beginning to be able to promote their own accommodation units. Promotional costs are not as expensive as conventional promotional media. Various promotional media such as Airbnb, booking.com, Agoda, Trip advisor and the like, offer the convenience of features and diversity of applications that can expose the reality of the accommodation offered. However, behind all the facilities, the community is faced with the challenge of the rapid tourist visits to remote areas. The increased visit of backpacker tourists has led to the birth of Bed Bunk accommodation. The question now is, to what extent does this promotional media influence the development of traditional Balinese houses today, and how the continuity of traditional rituals in the house after the online promotion media. The results of this study are expected to be used as an evaluation material for spatial improvement in Bali, especially residences as a result of uncontrolled accommodation development.

\section{RESEARCHMETHOD}

This research is a qualitative study that raises the phenomenon of the development of Bed Bunk accommodation in Canggu Village. This accommodation emerged and developed not apart from the influence of online promotional media that are not touched by local policies. The high demand for cheap accommodations encourages Canggu people to look for various forms of alternative accommodation that can accommodate many tourists with the backpacker lifestyle. The objects of this study are 100 Bed Bunk accommodations in Canggu Village that use online promotional media facilities (Airbnb, Agoda, booking.com, Tripadvisor, tiket.com, Traveloka). The facilities offered in this online media are used as an indicator to observe the demand for backpacker tourist spaces. The number of reviewers in each online promotion media in Canggu is used as an indicator to determine the number of accommodation requests. Reviewers are used as indicators, because someone who has given a review are people who have used the Bed Bunk facility, so that they know more about what they need and feel during their stay. The results of observations of the Bed Bunk are made in the form of tables and graphs which are then analyzed so that an overview of how far online promotional media influences the development of accommodations in Canggu Village is obtained. How to maintain the continuity of traditional activities and rituals among the interests of tourism. 


\section{BED BUNK DEVELOPMENT HistORY IN CANGGU VILLAGE}

Tourist accommodation is important in meeting the needs of tourists who are traveling. Setzer Munavizt (1958) states that "Accommodation is something that is provided to meet needs, such as a place to stay or temporary shelter for people who are traveling." Furthermore, Munavizt states that tourist accommodation can be a place where tourists can rest, stay, bathe, eat, drink and enjoy the services provided. Lodging is a form of accommodation for people who do activities not in their daily residence or outside the city for the benefit of things like travel, business, meetings and so forth. Badung Regency as one of the regions in Bali which has the largest income from the tourism sector, has a variety of types of tourist accommodation. Starting from a five-star hotel that has complete facilities, to a small homestay built for backpacker tourists. Canggu as one of the natural tourism areas based on Badung Regent Regulation No. 7 of 2005 dated 7 February 2005 concerning tourist attractions and tourist attractions in Badung Regency, has various types of accommodation. Ranging from city hotels to homestays that are sold at prices below Rp. 150,000 / night. The development of tourist accommodation types in Badung Regency, can be seen in table 1 below:

Table 1. Number of Accommodation Enterprises in Badung Regency 2018

\begin{tabular}{ccccccc}
\hline \hline \multirow{2}{*}{$\begin{array}{c}\text { T a h u n } \\
\text { Y e a r }\end{array}$} & \multicolumn{2}{c}{$\begin{array}{c}\text { Hotel Bintang } \\
\text { Classified Hotel }\end{array}$} & \multicolumn{2}{c}{$\begin{array}{c}\text { Hotel Melati } \\
\text { Simple Hotel }\end{array}$} & \multicolumn{2}{c}{$\begin{array}{c}\text { Pondok Wisata } \\
\text { Cottage }\end{array}$} \\
\cline { 2 - 6 } & $\begin{array}{c}\text { Jotal } \\
\text { Total }\end{array}$ & $\begin{array}{c}\text { Jumlah } \\
\text { Kamar } \\
\text { Total Rooms }\end{array}$ & $\begin{array}{c}\text { Jumlah } \\
\text { Total }\end{array}$ & $\begin{array}{c}\text { Jumlah } \\
\text { Kamar } \\
\text { Total Rooms }\end{array}$ & $\begin{array}{c}\text { Jumlah } \\
\text { Total }\end{array}$ & $\begin{array}{c}\text { Jumlah } \\
\text { Kamar } \\
\text { Total Rooms }\end{array}$ \\
\hline (1) & $(2)$ & $(3)$ & $(4)$ & $(5)$ & $(6)$ & $(7)$ \\
\hline 2009 & 98 & 16.360 & 505 & 11.463 & 395 & 1.986 \\
2010 & 98 & 16.360 & 541 & 12.657 & 475 & 2.296 \\
2011 & 98 & 16.360 & 596 & 15.561 & 599 & 2.696 \\
2012 & 98 & 16.360 & 697 & 22.684 & 719 & 3.013 \\
2013 & 98 & 16.360 & 778 & 28.330 & 837 & 3.372 \\
2014 & 98 & 16.360 & 855 & 34.815 & 999 & 3.937 \\
2015 & 155 & 24.683 & 458 & 28.282 & 685 & 2.405 \\
\hline 2016 & 155 & 24.683 & 521 & 33.075 & 775 & 2.750 \\
2017 & 155 & 24683 & 539 & 35698 & 839 & 2983 \\
2018 & 170 & 26.543 & 551 & 37.314 & 885 & 3.146 \\
\hline \hline
\end{tabular}

Source: Badung Dalam Angka, 2019

Based on the data in table 1 above it can be seen that, the type of accommodation that has experienced the most increase in Badung Regency in the last three years is a tourist cottage. From 775 units in 2016, by the end of 2018 the figure had reached 885 units. One of the villages in Badung Regency that has experienced the most significant tourist cottage development is Canggu Village, located in the North Kuta district. Based on the author's research results in Canggu Village, accommodations that have a tourist cottage permit are also regrouped into two criteria, namely Villa and Guest House. This guest house is divided into two, namely, a guest house that has one bed in the room, and a guest house that has more than 4 (four) beds in one room called the "monkey house" by the local community or as widely known in the world as "Bed Bunk". The classification of tourist cottages in Canggu can be seen in table 2 below:

Table 2. Types of accommodation that are classified as tourist cottage types in Canggu Village

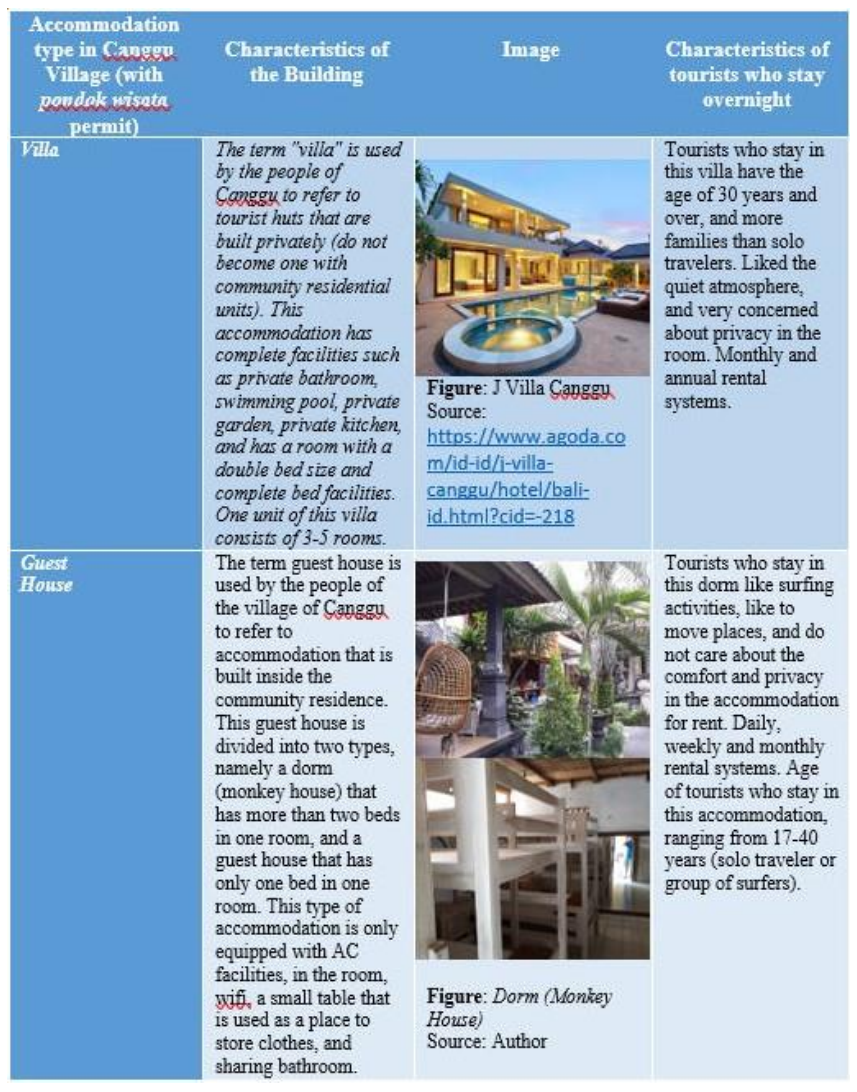

Source: Author

The road construction that connects Petitenget-Canggu Village is one of the main indicators of the development of tourism development in Canggu Village. With this road, the distance between Kuta and Canggu can be reached in less than 20 minutes. Alternative routes that previously had to rotate to the village of Kerobokan before reaching Canggu, in the period of the 2000s increasingly made shorter past the Petitenget Village, along the coast directly to Canggu. The only accommodation that was built in Canggu at the end of 1998 was the Tugu Batu Bolong Hotel. After the construction of the Tugu Hotel in 1998, there were not many changes felt by the people of Canggu. In 2003, the Badung Regency Government for the first time issued a policy through Badung Regent Decree No. 637 of 2003 concerning Spatial Planning in North Kuta District. This decree contains the determination of the function of the Canggu Coastal Area as a Tourism Zone (article 11 paragraph 2). After the issuance of the Badung 
Regent's Decree, it increasingly emphasized the designation of the tourist area in Canggu, so that investors would not hesitate to invest. The peak phase of the construction of tourist facilities in Canggu occurred in 2014. Many people's homes began to function as tourist accommodation. Construction of tourist facilities has been entered in all banjars (community) in Canggu. The entry of fbackpacker tourists into Canggu Village in the decade of 2014 has changed the face of the tourist cottage in Canggu Village. Demand for Bed Bunk is increasing. The relatively low capital of making Bed Bunk encourages the development of this type of accommodation. However, the problem experienced by local people is the marketing method. The community initially only relied on tourists who came directly to Canggu, without using digital promotional media. Over time, this method experienced many obstacles, so that there were several initiators using the online promotion media in collaboration with third parties.

\section{THE CONCEPT OF TRADITIONAL BALINESE HOUSE IN CANGGU COMMUNITY AREA}

In general, the plains of Balinese people in general are not a single unit of one roof, but rather a manifestation of space in a space that consists of many periods. Starting from the angkul-angkul that become one with the penyengker (perimeter fence) is the first building that can be found before entering the house, as well as functioning as a protective building in it. Kitchen (paon) is made separately from the bedroom, and the granary as a place to store rice. Entering the living room there is a core called natah. Natah is the center of the naming of buildings in traditional Balinese plains. The bedroom is divided into two buildings, namely Bale delod (located in the south of Natah) and Bale Daje (in the North of Natah). Bale Dangin as a place to perform the ceremony Manusa Yadnya located in the East Natah. The building which occupies a position in the main utamaning of a traditional Balinese house is the sanggah / pemajan (family sanctuary). The layout of traditional Balinese traditional house layout can be seen in the following figure;

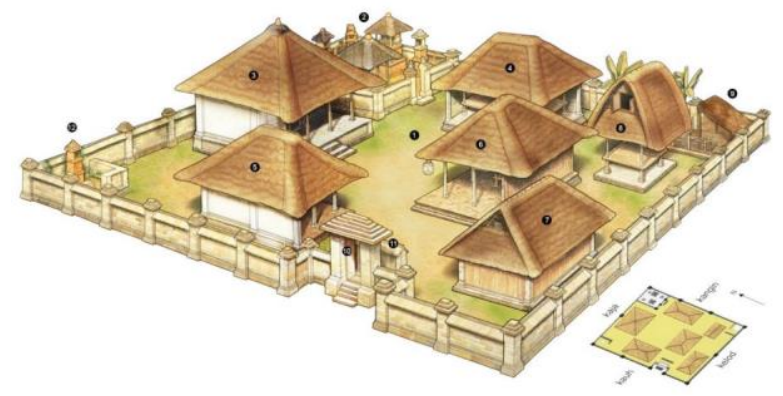

Figure 1. Arrangement of Spaces in Traditional Balinese House Sumber: ttps://en.wikipedia.org/wiki/Balinese_traditional_house

Based on the results of field observations, the physical form of the traditional home of the Canggu people seemed to break the concept of a linear pattern that only exists in mountainous areas. Starting access to the Canggu community housing unit there are angkul-angkul buildings of the same shape as those in Bali in general. The naming of the building has the same concept, which is the center point in the middle yard (natah). The kitchen is placed close to the main entrance of the site, where the kitchen has the meaning of neutralizing all negative auras before residents and visitors enter the residential area. After that there is a granary building which is placed adjacent to the kitchen (paon). Buildings that are used for beds have bale daje and bale delod. What is meant by the bale delod by the people of Canggu is the customary bale for the implementation of the Manusa Yadnya ceremony. Its position is not placed exactly east of Natah. The building that is just east of Natah prior to the presentation is Sanggah Natah. Sanggah Natah has a very important role in the development of building compositions in Canggu. The imaginary axis that determines the orientation of the building in the house, is between the sanggah natah and the entrance (angkul-angkul). This imaginary axis besides functions as the center of the orientation of the building period, this empty space also plays an important role in various ritual activities of the community.

As in the quarterly ritual, there are activities that surround this area three times. Sodok (2019) states that, this ritual has a very strong philosophical meaning for the people of Canggu. A guide to life that has always been a way of life for the people of Canggu. In this ritual it is illustrated that humans are not born into eternal living things. Humans will one day be in old age (elderly). Banana Heart (pusuh biu) which is carried by the mother during the ritual around Natah is a symbol of a baby born to the world as a new offspring in a family. After the mother, followed by the baby, a three-month ceremony attended by her grandparents. The obligation of grandparents who carry their grandchildren to this ritual, has the meaning that the grandfather and grandmother of the baby has given the family life relay to the baby who was born. Grandfather and grandmother in the future will depend on his grandchildren for this life until later they will pick up both. At a time when they are unable to actively work their big hopes, so that the next generation will be a good generation, dedicated to their parents and giving thanks to others. Behind grandparents, there is the father who carries a stick which is decorated with cloth (wastra) as a symbol of the defender (law enforcement of all family problems, and as the backbone of the family). This is where the baby's father is expected to remain upright when various household problems come up later.

\author{
V. Convergence of Online Promotion Media in The \\ DEVELOPMENT OF BED BUNK ACCOMMODATION IN CANGGU \\ VILLAGE
}


Nicholas Negroponte (1978) uses the term "convergence", to describe the meeting of the media industries. Convergence in social science occurs as a result of changes in community habits, not due to mere technological factors. Studying the development of Bed Bunk from the point of view of convergence theory, is an evaluation of the continuity of customs and culture and the sustainability of the arrangement of traditional Balinese residential spaces. The house is a reflection of a dynamic culture. The house is also an embodiment of a social relationship between residents and the surrounding environment. When humans as residents of the house and then plan for a change in occupancy, cannot be separated from various considerations. Humans as social creatures who always have a desire continuously, and never feel satisfied with what they already have. This condition motivates a person to make various changes in his life. Abraham H. Maslow in the Human Motivation Theory suggested the existence of a pyramid in human life. Changes that occur as a result of meeting the basic needs (physiological needs) to the formation of self-actualization to enhance dignity in society. Changes in human behavior and habits will greatly affect physical changes and the arrangement of space in residential units.

Canggu community in this matter also cannot be separated from change. Changes that occur in traditional Canggu homes, are not always caused by economic factors. $30 \%$ of the 100 accommodation owners interviewed indicated that resource persons from the middle to upper economic level made changes to the structure of the building period with the reason that they were following the rapidly growing tourism trend in Canggu, another $20 \%$ made changes due to their desire to own long term investment.

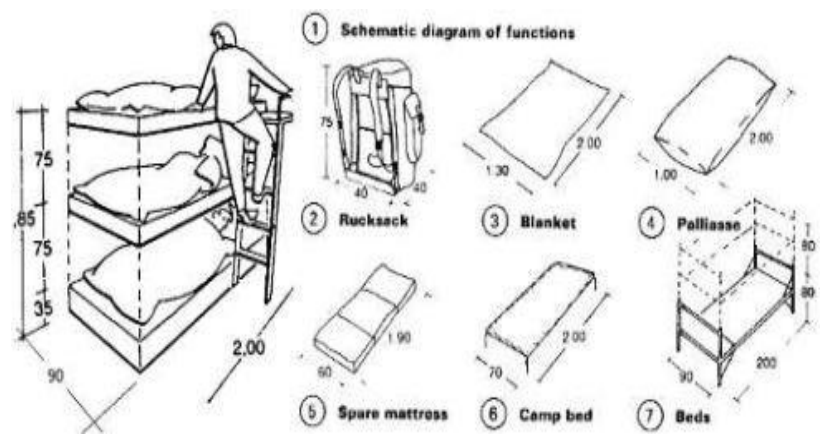

Figure 2. Bed Bunk Standard Source: Ernest Neufert Standard Eds. 3 (2000:471)

The hereditary trust, makes people maintain the space in their residential units. Not all people know the values or meaning of the space they have in the house. However, trust in the sacred value of the space or building, makes people think long for making significant changes. Defending space or buildings symbolically is one of the choices to keep traditional traditions. As for the graph of the ratio of factors that encourage Canggu people to make changes to the composition of the space in their homes, it can be seen in diagram 1 below:

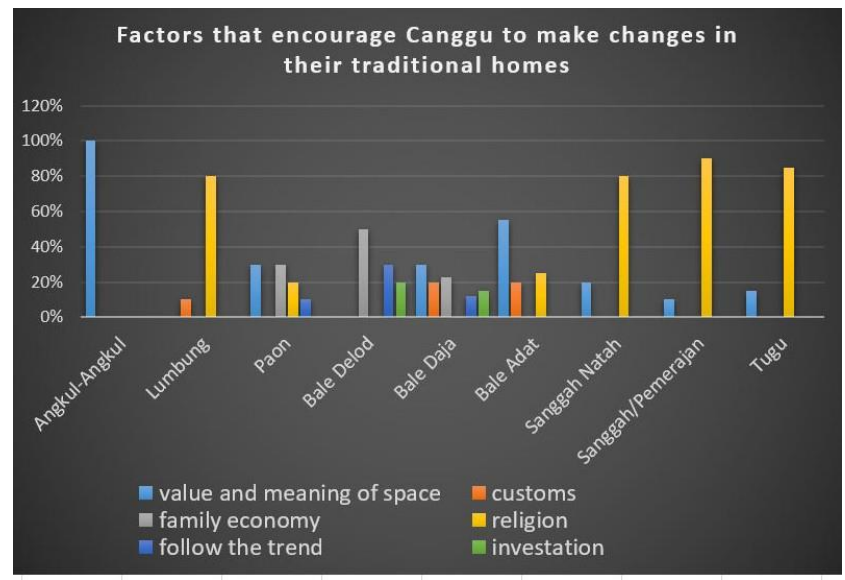

Figure 3. Factors that encourage Canggu to make changes in their traditional homes

Source: Author

Media promotion as one of the instruments used to attract tourist visits, greatly influences the changes in space that occur. While in the past the promotional media was limited to creative sketches and words, tourists could not clearly know the facilities that were in the accommodation. Even the most favorite accommodations cannot be exposed in detail. As shown in the following image;
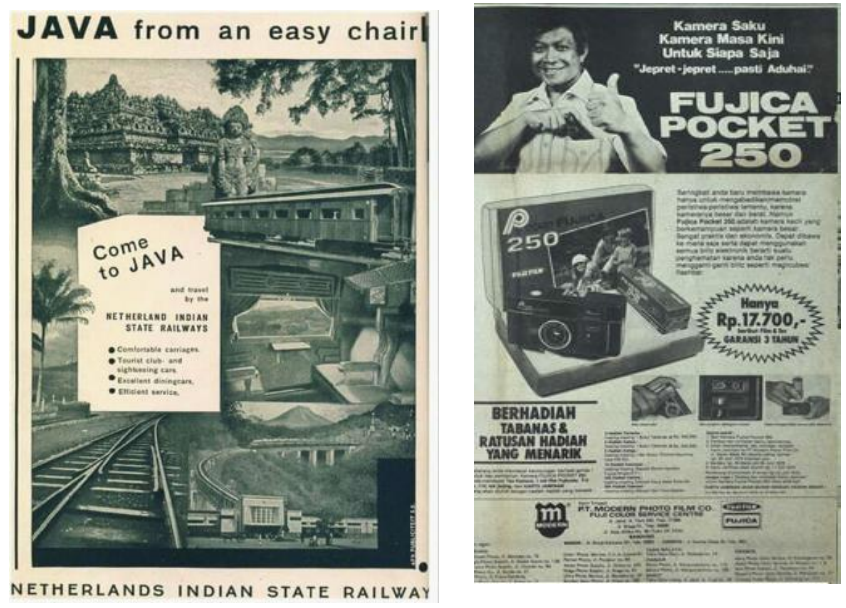

Figure 4. Promotional media in the past Source: https://www.pulsk.com/654155/

When promotional media develops online, many things can be exposed in it. Tourists can access detailed information such as the number of rooms, interiors, facilities, nearby attractions and so on, by accessing the subportal on the website, as shown in the following figure: 

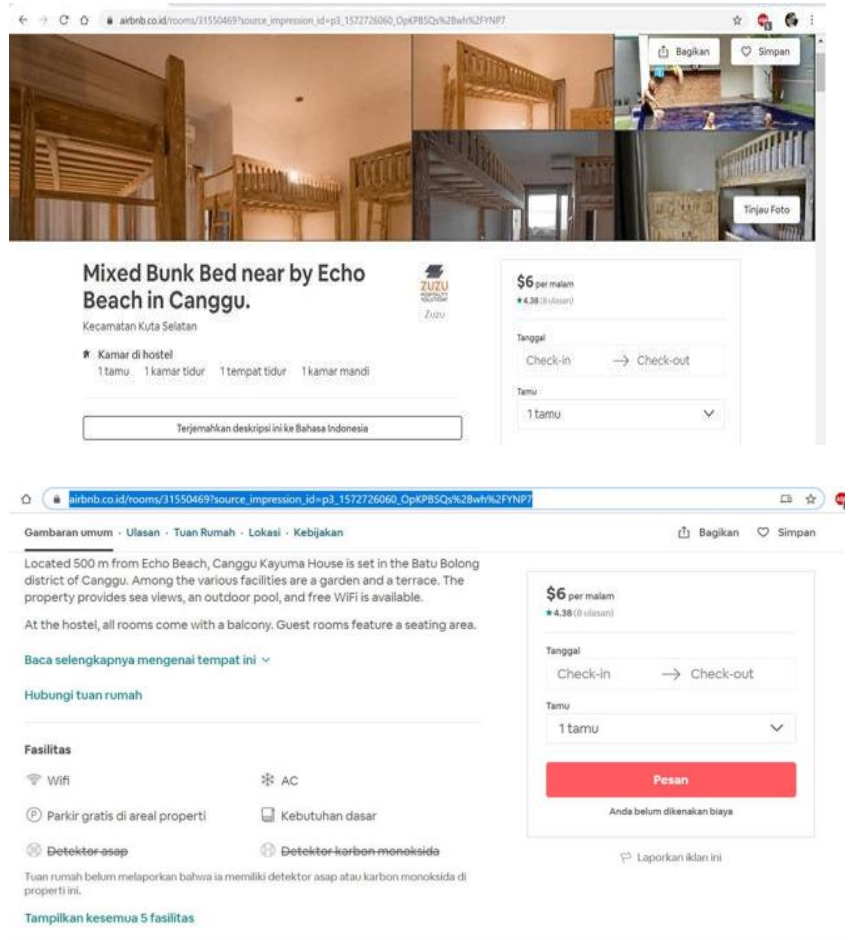

Figure 5. Digital media promotion Source :

https://www.airbnb.co.id/rooms/31550469?source_impression_id =p3_1572726060_OpKPBSQs\%2Bwh\%2FYNP7

One of the most important indicators to attract tourists is the subportal reviewer. Based on observations of 100 tourists who use bed bunk facilities in Canggu Village, the subportal in the online promotion media that most influences the decision to choose tourist accommodation is the subportal reviewer. Second is the consideration of the price per night and the third is the area of the room. The Subportal graph that greatly influences tourist decisions can be seen in the following figure:

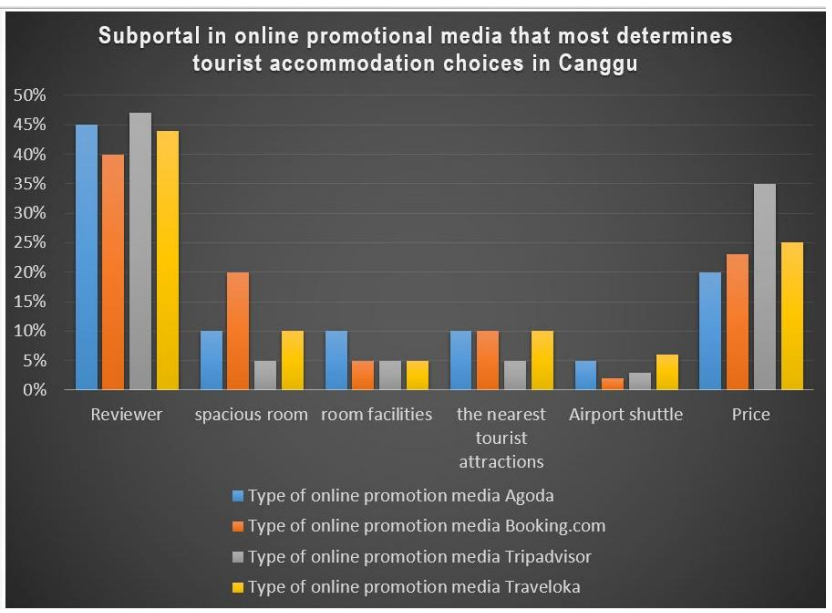

Figure 6. Subportal that most determines tourist accommodation choice in Canggu Source: Author

\section{CONCLUSION}

A bunk bed is a type of bed in which one bed frame is stacked on top of another, allowing two or more beds to occupy the floor space usually required by just one. They are commonly seen on ships, in the military, and in hostels, dormitories, summer camps, prisons, and the likes. Bunk beds are normally supported by four poles or pillars, one at each corner of the bed. A ladder is used to get to the upper bed, which is normally surrounded by a railing to prevent the sleeper from falling out. Some models also have a privacy curtain for the lower bunk. The growth of bed bunk in Canggu village is a phenomenon of convergence due to changes in media digitalization. However, the commercialization of these traditional dwellings does not make the customs, traditions and rituals that take place in Canggu traditional dwellings disappear. The ritual space is still maintained by prioritizing the symbol and meaning of space. Subportal reviewer as one of the main indicators that attracts tourists visiting one of the tourist accommodations, greatly influences spatial development. Accommodation that has a high reviewer value will be increasingly dense, so that the surrounding area is also increasingly out of control. Badung district government should start building an automatic connection network with online promotional media, so that the real facts of the number of bed bunk in the field can be easily detected. With the detection of real tourism accommodation conditions in the field, it is hoped that they can be used as a basis for limiting cheap accommodation which is currently increasingly out of control.

\section{ACKNOWLEDGMENT}

Acknowledgments to those who have supported the writing of this paper are all my supervisor at Udayana University and the Engineering Faculty of Udayana University, also Mahendradatta University for the support of research grants and Village Head and all the owners of the bed bunk in Canggu Village.

\section{REFERENCES}

[1] Arzeni, S. (2009). The Impact of Culture on Tourism (978-92-64-05648-0). France: OECD Publisher Retrieved from ww.sourceoecd.org/Industryservicestrade/9789264056480

[2] Christina Gantini, J. P., Yuswadi Saliya, Dwinik Winawangsari. (2011). Traditional Balinese Architecture: What is Thought and What is Seen. Paper presented at the 1st Biennale ICIAP (International Conference on Indonesian Architecture and Planning).

[3] Creswell, J. W. (2014). Research Qualitative, Quantitative and Design. United State of America: SAGE Publication Inc.

[4] Dallen J.Timothy, V. B. T. (2009). Tourism and The Lodging Sector (1st ed.). United State of America: ELSEVIER.

[5] Dwijendra, N. K. A. (2003). "Perumahan dan Permukiman Tradisional Bali." Permukiman "Natah" 01(01): 8-24.

[6] Fajar, A. (2011). Konvergensi Dalam Social (New) Media (Kajian Tradisi Kritis Sosial Budaya Terhadap Teoritisasi Komunikasi Antar Pribadi, Massa Dan Digital). Paper presented at the Seminar Nasional Teknologi Informasi \& Komunikasi Terapan (SEMANTIK), Yogyakarta.

[7] Hory Gergely, Z. M., Peter Mullner,Melinda Benko. (2017). Exploration of Spatial Design Issues at Backpacker Hostels In 
International Journal of Engineering and Emerging Technology Vol. 4 No. 2 July - December 2019

Budapest's Historic Center: Informality, Density, Adaptability.

Frontiers Of Architectural Research, 6, 157-168.

[8] Kiliçaslan, H. (2013). Design of Living Spaces in Dormitories. Procedia - Social and Behavioral Sciences. doi:10.1016/j.sbspro.2013.08.699

[9] Munyaradzi Mawere, T. R. M., Mirjan van Reisen,Gertjan van Stam. (2016). Maslow's Theory of Human Motivation and it's Deep Roots in Individualism: Interrogating Maslow's Applicability in Africa.

Retrieved from https://www.researchgate.net/publication/302516151

[10] Moh.Wildan. (2014). The Symbolic Convergence of Cyberspace Communications. Jurnal Masyarakat Telematika dan Informasi, 5(2), 209-232.

[11] Ruonavaara, H. (2018). Theory of Housing, From Housing, About Housing. Housing Theory and Society, 35(2), 178-192. doi:10.1080/14036096.2017.1347103

[12] Sufyati. (2019). Konvergensi Media Dalam Religiusitas Masyarakat. Sosiologi Reflektif, 13(2).

[13] Sri Efrinita Irwan, T. M. (2019). A graph theory approach to the dormitory room placement problem. Journal of Science and Applicative Technology, 111-118. doi:https://doi.org/10.35472/281472.

[14] Suryadi, I. (2010). Teori Konvergensi Simbolik. Jurnal Academica Fisip Untad, 2(2). 